\title{
Publisher's Foreword
}

This account does not carry Pancho Villa to the end of his life. It ends in 1915 as he was preparing for new battles in the internecine warfare among the Revolutionary generals which followed the triumph of the Revolution. Martín Luis Guzmán, author of this volume, has the necessary materials and records at hand and plans to complete the story at some future time.

The Spanish version of these Memoirs has been somewhat condensed in translation by eliminating, with no indication of ellipses, some of Villa's repetitions and redundancies.

The University of Texas Press wishes to express its great appreciation to the El Paso Public Library and to Walter N. Babbitt, director of the Library, for making available extensive files of pictures of the Villa period. The Press is especially indebted to C. L. Sonnichsen, dean of the Graduate Division of Texas Western College, El Paso, for valuable assistance in locating and identifying pictures.

The Press, the author, and the translator are extremely grateful to Robert C. Stephenson, of the University of Puerto Rico, for his careful review of the manuscript. 
THIS PAGE INTENTIONALLY LEFT BLANK 